\title{
The Validity of Concept Attainment With Multi Representation as an Alternative Learning Model to Improve Students' Mastery of Concepts and Scientific Consistency
}

\author{
Pramonoadi $^{1}$, S Tresnaningsih ${ }^{1}$, A Faqih ${ }^{1}$, R Setiani $^{2},{ }^{*}$ Dwikoranto $^{3}$ \\ 1Open University UPBJJ-UT Surabaya, Indonesia \\ 2Bhinneka PGRI University of Tulungagung, Indonesia \\ 3Department of Physics, Faculty of Mathematics and Natural Science, Universitas Negeri Surabaya, Surabaya 60231, \\ Indonesia
}

\begin{tabular}{l} 
Article Info \\
\hline Article history: \\
Received 16, July 2020 \\
Revised 29, August 2020 \\
Accepted 30, August 2020 \\
Available Online 31, August 2020 \\
\hline
\end{tabular}

Keywords:

Concept attainment Mastery of concepts Multi representation Scientific consistency Validity

\begin{abstract}
The concept attainment tutorial tool with multi representations still needs to be developed. The purpose of this study is to describe the validity of the model and the validity of concept attainment devices with multi representations as alternative learning models to improve students' mastery of concepts and scientific consistency. The development of this tutorial tool uses the design of Plomp which consists of preliminary study phase, prototype stage, and assessment phase. The limited test was conducted on students of the Surabaya Open University in the Basic Science Natural Sciences course (PDGK4103). Research data were collected by the validation method using the model validation sheet instrument and the device validation sheet. Data were analyzed using qualitative descriptive analysis. The results of the study show that: (1) The concept of attainment model with multi representations developed is included in the valid criteria in terms of content validity and construct validity. (2) The multi-representation tutorial tool developed is included in the valid criteria. Based on the above it can be concluded that the concept of attainment with multi representations developed is valid and appropriate to be used to improve students' mastery of concepts and scientific consistency.
\end{abstract}

\section{INTRODUCTION}

The concept of attainment with multi-representation model is a product of the learning model developed by including aspects of multi-representation in the implementation stage. According to Nieveen and Folmer (2013) the framework of a product consists of three criteria, namely validity, practically and effectiveness. If it is focused on the element of validity, then the concept attainment model with multiple representations contains at least two elements of validity, namely content validity and construct validity. content validity in question is that all components that make up the model must be based on the need and state of the art of knowledge, and construct validity is intended that all components must be consistently related to one another.

The learning model is a teaching process that is broad and comprehensive, has a coherent theoretical foundation or foundation of thought about the learning objectives to be achieved, the teaching behavior, and the learning environment needed to achieve the learning objectives (Arends, 2012). So, the concept attainment model with multi representations is a broad and comprehensive teaching design in the form of guidelines that guide lecturers to improve their 
mastery of concepts and scientific consistency as basic skills in constructing learning material using multi representations.

The multi-representation ability possessed by students shows a level of mastery that is stronger, more robust, and comprehensive on the concepts they learn. Representation as a configuration that can describe, represent or symbolize something in a way (Murtono et al., 2015; Dufresne et al., 1997). Whereas multi representation as a way to present various representations to instill a concept in the minds of students needs to be trained to students of Primary School Teacher Education (PSTE).

Murtono et al. (2015) stated the mastery of multi-representation-based concepts that were tested on students of Natural Science basic course subjects obtained results had not yet reached the value of 70 . The form of the questions tested consisted of three themes and one theme consisted of three representations namely mathematical representation, representation verbal, and graphical or picture representation. Students are still weak in working on problems in verbal representations, out of three questions verbal representations $6.67 \%$ are able to answer correctly, whereas in mathematical representations $50 \%$ are able to answer correctly, and in graphical representations there are $20 \%$ who answer right. Students apparently are still lacking in mastery of concepts and are weak in multi-representation questions. Consistency test results inside students apparently are still lacking in mastery of concepts and are weak in multirepresentation questions. Consistency test results in answering questions, students are still not consistently answering questions. This can identify that they do not understand the concepts being taught so that when the same concept is presented in the form of different representations it cannot be answered correctly. Therefore, in the tutorial process, it is advisable to have adequate concept mastery so that when the concept is presented in different representations it is able to answer correctly so that it can be said to be scientifically consistent (Setyowati et al., 2019).

Sutopo et al. (2015) states that multi-representation tutorials can improve concept mastery. Based on this, it is expected that by applying a multi representation-based approach able to practice the ability of representation. Multi representation has three main functions namely, to complete representation, to limit and guide other representations and the third to build deeper understanding of concepts (Nieminen et al., 2010; Zou, 2010; Homer \& Bowen-Jones, 2014). One of the main functions of multi representation is to build a deeper understanding of concepts, with this function it is expected that the multi representation approach can improve the mastery of concepts (Tresnaningsih et al., 2019; Widianingtiyas et al., 2015).

Open University students in the general Science Basic Concept tutorial will remember the information delivered by the tutor if it is interesting in the delivery and the tutor masters the material being taught, so that it can be easily reappeared in problem solving even though it is possible without understanding its meaning. Besides the ability of representation developed in verbal descriptions is changed in the form of other representations such as symbols, graphs, pictures, tables, and sometimes vice versa. So that this research is expected to help improve scientific consistency. The definition of scientific consistency is consistency in answering questions and seeing the equality of representation of the concept according to what is believed to be true, and whether the answer is scientifically correct or not in the sense that the answer must be conceptually correct (Tresnaningsih et al., 2019).

Concept Attainment as a tutorial model is a concept achievement tutorial model designed to develop students' ability to think inductively. Inductive thinking is a thought process that goes from something that is specific to something that is general. The use of the concept attainment tutorial model with a multi-representation approach is expected to be able to make understanding of the concepts of Natural Sciences so that they can represent these concepts in various forms that will make mastery of the concepts of Natural Sciences increase. The contents of the course Basic Science Concepts in Elementary School (PDGK4103) are about living things and the universe, namely about the characteristics and diversity of living things, living things 
and their environment, human organs, the development of living things, the structure of the human body, food, health, disease and its prevention, kinematics and dynamics, matter and its properties, waves and sound, optics, electricity and magnetism, earth and the universe (Sumardi et al., 2008).

The results of research conducted by Admoko et al. (2017) showed that the treatment of problem-based learning with multiple representations, scientific consistency increased by 0.38 was in the medium criteria and there was an increase in learning outcomes with a gain of 0.44 being in the moderate criteria. Research conducted by Setyaningrum (2014) and Taqwa et al. (2020) shows that the tutorial model for achieving concepts can improve learning outcomes with moderate gain values. While the results of the study (Kurnaz \& Arslan, 2014; Sari et al., 2015) show that tutorials using multiple representations have a good effect on the mastery of concepts, as well as providing meaningful learning to students. The facts outlined above encourage researchers to use the Concept Attainment tutorial model with multi representations to improve mastery of concepts and scientific consistency (Ulfarina, 2010).

Based on the background stated above, the following problem statements can be taken.

1. How is the content and construct validity of the concept attainment model with multi representations developed to improve the mastery of concepts and scientific consistency of PSTE students?

2. How is the validity of tutorial tools developed to improve the mastery of the concepts and scientific consistency of PSTE students?

In accordance with the formulation of the problem, the objectives of this study are:

1. Describe the content and construct validity of the concept attainment model with multi representations developed to improve the mastery of concepts and scientific consistency of PSTE students.

2. Describe the validity of the tutorial tools developed to improve the mastery of concepts and scientific consistency of PSTE students.

Tutorial with the concept attainment model with multi representation is important because it will provide a tutorial activity design tutorial tool (DAT), Tutorial Program Unit (TPU), Student Activity Sheet (SAS) and an Instrument to measure the mastery of basic concepts of science in Elementary Schools and an Instrument to measure consistency scientific PSTE students. Therefore, in the tutorial in the PSTE class, it is expected that there will be an improvement in the process and student learning outcomes. In general, there are two benefits that can be drawn from this research. First, the benefits of practice that has a direct impact on all learning components. Second, the theoretical benefits of having long-term access in the development of the concept representation learning tool with multi representations.

\section{RESEARCH METHOD}

This type of research is development research used to produce certain products and test the effectiveness of the products produced (Nieveen \& Folmer, 2013). This study uses educational design research to develop research-based problem solutions in solving complex problems in education (Plomp, 2013). This study aims to produce a valid representation-based Concept Attainment tutorial model to improve students' mastery of concepts and scientific consistency, as well as equipped with learning tools including DAT, TPU and SAS to determine the level of validity of the developed tutorial model.

This research was conducted during the registration period 2018.1 and 2018.2 at UPBJJ-UT Surabaya in Pokjar Bojonegoro according to the official schedule issued by UPBJJ-UT Surabaya. The research subject is a multi-representation concept-based concept attainment tutorial model. The test was chosen for undergraduate students of PSTE who programed the basic concepts of science courses in elementary school. 
The development of the concept attainment tutorial model and its supporting devices using the design adaptation of the Plomp model development (Plomp, 2013) with the development procedures to be carried out are described as follows:

\section{Preliminary Research}

The preliminary research uses a qualitative research approach to find out the basic problems needed in developing the tutorial model and its supporting tools which will be explained as follows: (a) Literature review, analyzing the model development needs by examining various literatures on challenges and demands of $21^{\text {st }}$ century competencies, various studies relevant, scientific consistency, and Plomp model development theory (Plomp, 2013) in order to obtain a description of learning patterns that are considered ideal. (b) Context analysis to be taught using the tutorial model is done through: (1) material analysis, selecting and assigning, systematically detailing and compiling the Basic Concepts of Science material in elementary schools, (2) task analysis, identifying key competencies in the curriculum emphasized development of learning outcomes, especially scientific consistency of students, then analyze them in an academic sub-skills framework that will be developed in learning, and (3) competency specifications expressed in mastering student content and performance. (c) Field studies about tutorials on Science Concept Basic courses in elementary school, an analysis of the characteristics of mastery of scientific consistency and mastery of student concepts is analyzed.

\section{Prototype Stage}

The design process is done in cycles in the form of a more micro research process and uses formative evaluation to improve and improve the intervention model (Nieveen, 2013; Plomp, 2013). The steps undertaken at this stage are: (a) Designing prototypes with DAT, TPU, SAS devices. (b) Prototype validation. (c) Modeling. (d) Research trials. The research trials use a quantitative research approach to see the extent of practicality and effectiveness of the model in classroom learning.

\section{Assessment Phase}

Assessment is the development process to get a valid final prototype. The data needed to develop the Concept Attainment model is obtained through a literature review, learning theories from standard books, various relevant research journals, and the results of preliminary studies. The tutorial model validation data was obtained through expert validation by filling in the Instrument Validation Sheet Content Tutorial Model, the Model Construct Validity Validation Instrument Sheet. Validation Tool Tutorial data with Concept Attainment model obtained through expert and practitioner validation by filling in the DAT Validation Instrument Sheet, TPU, SAS Validation Sheet, validation results of Concept Concept Attainment Model and its Supporting Devices (DAT, TPU, SAS) analyzed descriptively qualitative. In this study passing grade is the average score $(\mathrm{P})$ from the results of the assessment of experts and practitioners, then adjusted to the validation assessment criteria as in Table 1 below.

Table 1. Criteria for categorizing model validations

\begin{tabular}{lll}
\hline Score Interval & Assessment Category & \multicolumn{1}{c}{ Information } \\
$3.25 \leq \mathrm{P}<4.00$ & Very valid & can be used without revision \\
$2.50 \leq \mathrm{P}<3.25$ & Valid & can be used with a slight revision \\
$1.75 \leq \mathrm{P}<2.50$ & Rather valid & can be used with many revisions \\
$1.00 \leq \mathrm{P}<1.75$ & Less valid & not used yet and still requires consultation \\
\hline
\end{tabular}

Adapted from (Ministry of Education, 2006; Hake, 1998)

Reliability of the results of the validation of the Concept Attainment model along with supporting devices is determined using the percentage of agreement formula. The validation results are said to be reliable if the reliability value is\% 75\% (Borich, 2011). 


\section{RESULTS AND DISCUSSION}

\section{Validation of Concept Attainment Model}

\subsection{Content Validity of Concept Attainment Model}

The results of the content validity of the concept attainment model are briefly presented in Table 2.

Table 2. Content validity results of the concept attainment model

\begin{tabular}{|c|c|c|c|c|c|}
\hline No. & Statement & Average & Criterion & Reliability & Criterion \\
\hline \multicolumn{2}{|c|}{$\begin{array}{l}\text { The Need for Developing Concept Attainment } \\
\text { Models }\end{array}$} & 8.46 & VVa & $95.24 \%$ & Reliable \\
\hline 1 & Loading $21^{\text {st }}$ century skills & 8.66 & VVa & $94.12 \%$ & Reliable \\
\hline 2 & Supports Higher Education Standards & 9.00 & VVa & $100.0 \%$ & Reliable \\
\hline 3 & $\begin{array}{l}\text { Bridging the gap between expectations } \\
\text { and the reality of learning today. }\end{array}$ & 8.66 & $\mathrm{VV}^{\mathrm{a}}$ & $94.12 \%$ & Reliable \\
\hline 4 & $\begin{array}{l}\text { Recommendations for improvement of } \\
\text { some innovative learning }\end{array}$ & 8.34 & VVa & $94.12 \%$ & Reliable \\
\hline 5 & $\begin{array}{l}\text { Referring to INQF (Indonesian National } \\
\text { Qualification Framework). }\end{array}$ & 7.66 & VVa & $93.33 \%$ & Reliable \\
\hline \multicolumn{2}{|c|}{$\begin{array}{l}\text { Design Concept Attainment Model based on } \\
\text { the latest knowledge }\end{array}$} & 8.33 & $\mathrm{VV}^{\mathrm{a}}$ & $95.12 \%$ & Reliable \\
\hline 6 & Development of goals & 8.33 & $\mathrm{VV}^{\mathrm{a}}$ & $94.12 \%$ & Reliable \\
\hline 7 & Use of theoretical foundation & 8.33 & VVa & $94.12 \%$ & Reliable \\
\hline 8 & Use of empirical foundation & 7.60 & VVa & $93.33 \%$ & Reliable \\
\hline 9 & Development planning & 8.67 & VVa & $94.12 \%$ & Reliable \\
\hline 10 & Development implementation & 8.60 & VVa & $94.12 \%$ & Reliable \\
\hline 11 & Development of learning environment & 8.00 & $\mathrm{VV}^{\mathrm{a}}$ & $100.0 \%$ & Reliable \\
\hline 12 & Development of assessment & 8.67 & VVa & $94.12 \%$ & Reliable \\
\hline 13 & Efforts to encourage further research & 8.00 & $\mathrm{VV}^{\mathrm{a}}$ & $100.0 \%$ & Reliable \\
\hline & Average & 8.40 & VV & $94.97 \%$ & Reliable \\
\hline
\end{tabular}

aVery Valid

Table 2 shows that the value of the content validity of the model in terms of the need for the development of the model to produce competencies that support the needs of 21st century skills, supports the application of INQF in accordance with NSTE (National Standard of Tertiary Education), bridges the gap between expectations and reality of modern learning, especially the low scientific consistency and understanding concepts, and according to recommendations for improvement of innovative learning get very valid criteria. Each aspect of needs assessment for model development has met the validity criteria (Widianingtiyas et al., 2015; Dwikoranto et al., 2018).

The validity of the model content is reviewed from the basis of current knowledge in developing model objectives, theoretical baseline support, empirical baseline support, planning development, implementation, learning environment, learning assessment, and efforts to encourage further research to obtain highly valid assessment criteria (Nieveen \& Folmer, 2013). Every aspect of the assessment of the latest knowledge base meets the validity criteria. The reliability coefficient of all aspects of the model content validity are in the range of $93 \%-100 \%$. The reliability coefficient is above the inter-observer agreement provision of $75 \%$ (Borich, 2011), so that the results of the assessment of the validity of the model content are reliable (Suyidno et al., 2017). 


\subsection{Construct Validity of Concept Attainment Model}

Tabel 3. Construct validity results of concept attainment model

\begin{tabular}{|c|c|c|c|c|c|}
\hline No. & Rated aspect & Average & Criterion & Reliability & Criterion \\
\hline A. & $\begin{array}{l}\text { Learning Outcomes or Learning } \\
\text { Objectives }\end{array}$ & 9.00 & $\mathbf{V V}^{\mathbf{a}}$ & $94.44 \%$ & Reliable \\
\hline 1 & Improve scientific consistency & 9.33 & $\mathrm{VV}^{\mathrm{a}}$ & $94.74 \%$ & Reliable \\
\hline 2 & Improve mastery of concepts & 8.67 & $\mathrm{VV}^{\mathrm{a}}$ & $94.12 \%$ & Reliable \\
\hline B. & Theoretical and Empirical Support & 8.56 & $\mathbf{V V}^{\mathbf{a}}$ & $96.08 \%$ & Reliable \\
\hline 1 & Motivation theory & 9.33 & $\mathrm{VV}^{\mathrm{a}}$ & $94.74 \%$ & Reliable \\
\hline 2 & Piaget's constructivist theory & 8.33 & $\mathrm{VV}^{\mathrm{a}}$ & $94.12 \%$ & Reliable \\
\hline 3 & Inquiry learning theory & 8.67 & $\mathrm{VV}^{\mathrm{a}}$ & $94.12 \%$ & Reliable \\
\hline 4 & Zone of proximal from Vigotsky theory & 8.33 & $\mathrm{VV}^{\mathrm{a}}$ & $94.12 \%$ & Reliable \\
\hline 5 & Assessment theory & 8.33 & $V^{a}$ & $94.12 \%$ & Reliable \\
\hline 6 & empirical support & 8.33 & $\mathrm{VV}^{\mathrm{a}}$ & $94.12 \%$ & Reliable \\
\hline C. & Syntax & 8.83 & $V^{a}$ & $97.14 \%$ & Reliable \\
\hline 1 & $\begin{array}{l}\text { Describe the procedures for achieving } \\
\text { learning outcomes. }\end{array}$ & 9.00 & $\mathrm{VV}^{\mathrm{a}}$ & $100.00 \%$ & Reliable \\
\hline 2 & $\begin{array}{l}\text { Supported by constructivist theory, } \\
\text { motivational theory, Vigotsky, inquiry, } \\
\text { assessment. }\end{array}$ & 9.00 & VVa & $100.00 \%$ & Reliable \\
\hline 3 & $\begin{array}{l}\text { The role of the lecturer is clearly } \\
\text { illustrated. }\end{array}$ & 8.67 & $\mathrm{VV}^{\mathrm{a}}$ & $94.12 \%$ & Reliable \\
\hline 4 & $\begin{array}{l}\text { Can be implemented lecturers in } \\
\text { learning. }\end{array}$ & 8.67 & $\mathrm{VV}^{\mathrm{a}}$ & $94.12 \%$ & Reliable \\
\hline D. & $\begin{array}{l}\text { Learning Environment Management } \\
\text { Guidelines }\end{array}$ & 8.67 & $\mathbf{V V}^{\mathbf{a}}$ & $95.65 \%$ & Reliable \\
\hline 1 & $\begin{array}{l}\text { Setting individual and group } \\
\text { combinations. }\end{array}$ & 8.67 & $\mathrm{VV}^{\mathrm{a}}$ & $94.12 \%$ & Reliable \\
\hline 2 & Contextual in nature & 8.33 & VVa & $94.12 \%$ & Reliable \\
\hline 3 & Tutorial Stages & 9.33 & $\mathrm{VV}^{\mathrm{a}}$ & $94.74 \%$ & Reliable \\
\hline 4 & $\begin{array}{l}\text { The final result of the activity is a } \\
\text { conclusion about the basic concepts of } \\
\text { natural science, the results of the work } \\
\text { on the mastery of concepts and } \\
\text { scientific consistency }\end{array}$ & 8.33 & $\mathrm{VV}^{\mathrm{a}}$ & $94.12 \%$ & Reliable \\
\hline & $\begin{array}{l}\text { Average } \\
\end{array}$ & 8.71 & $V^{a}{ }^{a}$ & $95.22 \%$ & Reliable \\
\hline
\end{tabular}

aVery Valid

Table 3 shows the results of the construct validity assessment of the internal components of the model including learning objectives and outcomes (9.00), theoretical and empirical support (8.56), syntax or learning steps (8.83), and management of the learning environment (8.67). The overall score of the validator is 8.71 . The average reliability of the validator assessment results is 95.22\% which means Reliable. This value also shows that every aspect of model construct validity meets the validity criteria and the criteria are very valid. Based on the results of the assessment of the validator, all construct validity indicators get a minimum value of 8 in the highly valid criteria. This shows that all indicators of the four characteristics of the learning model are construct valid (Suyidno et al., 2017; Dwikoranto et al., 2018). 


\section{Validation of Concept Attainment Model Devices}

\subsection{Validity of the DAT Device}

DAT validation criteria are generally categorized into two types, namely relating to the completeness of the DAT components and the steps of learning activities. The validation results of the DAT device are presented in Table 4.

Table 4. Validity results of DAT device

\begin{tabular}{lcccc}
\hline \multirow{2}{*}{ Topics } & \multicolumn{4}{c}{ Assessment Aspects } \\
\cline { 2 - 5 } & \multicolumn{2}{c}{ Completeness of } & Learning Activities \\
& Components DAT & Criterion & Average & Criterion \\
\cline { 2 - 5 } & Average & Very Valid & 8.36 & Very Valid \\
Force and Motion & 8.43 & Very Valid & 8.43 & Very Valid \\
Energy and its changes & 8.60 & Very Valid & 8.57 & Very Valid \\
Temperature and & 8.50 & & & \\
Measurement & & Very Valid & 8.48 & Very Valid \\
Thermal energy & 8.50 & Very Valid & 8.45 & Very Valid \\
Sound Waves & 8.63 & Very Valid & 8.55 & Very Valid \\
Light waves & 8.47 & Very Valid & $\mathbf{8 . 4 7}$ & Very Valid \\
\multicolumn{1}{c}{ Average } & $\mathbf{8 . 5 2}$ &
\end{tabular}

Table 4. shows that the validity of the DAT (Design Activity Tutorial) includes aspects of completeness of the DAT component and learning activities in the Very Valid criteria. The validators provide suggestions for adjusting the time allocation with the number of learning objectives to be achieved, the activities in the delivery phase of the objectives are clarified with media examples of specific methods and conveyed more clearly about the process of selfassessment (Suhandi \& Wibowo, 2012; Widianingtiyas et al., 2015; Dwikoranto et al., 2018).

\subsection{Validity of TPU (Tutorial Program Unit)}

The validation criteria for the Tutorial Program Unit (TPU) are generally categorized into four feasibility components, which are related to the content, presentation, language, and graphic components. The results of the validation of the TPU device are presented in Table 5.

Table 5. Validity results of TPU

\begin{tabular}{|c|c|c|c|c|c|}
\hline \multirow{2}{*}{ Eligibility Component } & \multicolumn{3}{|c|}{ Score } & \multirow{2}{*}{ Average Score } & \multirow{2}{*}{ Criterion } \\
\hline & Validator 1 & Validator 2 & Validator 3 & & \\
\hline Content of TPU & 9.25 & 9.06 & 9.34 & 9.12 & Very Valid \\
\hline Presentation & 9.42 & 9.02 & 8.85 & 9.11 & Very Valid \\
\hline The language used & 9.12 & 8.96 & 9.11 & 9.04 & Very Valid \\
\hline Graphics & 9.18 & 9.23 & 9.22 & 9.23 & Very Valid \\
\hline Average Score & 9.24 & 9.06 & 9.15 & 9.14 & Very Valid \\
\hline
\end{tabular}

Table 5. shows that the validity of the TPU for the components included the content component (9.12), the presentation component (9.11), the language component (9.04), and the graphic component (9.23). Each validator gives an average rating of more than 9, with an overall average of 9.14, meaning that the validator assesses that the TPU is very valid, and according to the evaluation criteria on the validation instrument, the average value is included in the criteria very well. It means that the device developed is feasible to use (Nieveen \& Folmer, 2013; Borich, 2011; Suyidno et al., 2017; Dwikoranto et al., 2019).

\subsection{Validity of SAS Tools}

Assessment of student activity sheets (SAS) is carried out with instruments developed by researchers. The instrument includes 4 aspects of eligibility, namely didactic, content, 
presentation, and time. Each of these aspects has several feasibility components as shown in Table 6.

Table 6. Validity results of SAS tools

\begin{tabular}{|c|c|c|c|c|c|c|}
\hline \multirow{2}{*}{\multicolumn{2}{|c|}{ Feasibility Component }} & \multicolumn{3}{|c|}{ Score } & \multirow{2}{*}{$\begin{array}{l}\text { Average } \\
\text { Score }\end{array}$} & \multirow{2}{*}{ Information } \\
\hline & & V 1 & V 2 & V3 & & \\
\hline \multicolumn{7}{|c|}{ Didactic method } \\
\hline & $\begin{array}{l}\text { Appropriate Learning } \\
\text { Outcomes }\end{array}$ & 9 & 8 & 10 & 9.00 & Very good \\
\hline & Grooves of material flow & 9 & 8 & 10 & 9.00 & Very good \\
\hline & $\begin{array}{l}\text { Facilitating students to do } \\
\text { inquiry }\end{array}$ & 8 & 9 & 9 & 8.67 & Very good \\
\hline & $\begin{array}{l}\text { Facilitating students to } \\
\text { evaluate themselves }\end{array}$ & 9 & 9 & 9 & 9.00 & Very good \\
\hline \multicolumn{7}{|c|}{ Content } \\
\hline & Complete component & 9 & 10 & 9 & 9.33 & Very good \\
\hline & $\begin{array}{l}\text { Relevant to the context of } \\
\text { everyday life }\end{array}$ & 9 & 8 & 9 & 8.67 & Very good \\
\hline & $\begin{array}{l}\text { Case examples are in } \\
\text { accordance with learning } \\
\text { objectives }\end{array}$ & 9 & 8 & 8 & 8.33 & Good \\
\hline & $\begin{array}{l}\text { The understanding test } \\
\text { questions are in accordance } \\
\text { with learning outcomes }\end{array}$ & 8 & 8 & 9 & 8.33 & Good \\
\hline \multicolumn{7}{|c|}{ Presentation } \\
\hline & $\begin{array}{l}\text { Language according to } \\
\text { rules }\end{array}$ & 9 & 9 & 9 & 9.00 & Very good \\
\hline & $\begin{array}{l}\text { Simple and easy to } \\
\text { understand the language }\end{array}$ & 9 & 9 & 9 & 9.00 & Very good \\
\hline & $\begin{array}{l}\text { Proportional font type and } \\
\text { size }\end{array}$ & 9 & 9 & 9 & 9.00 & Very good \\
\hline & $\begin{array}{l}\text { Illustration / Image helps } \\
\text { understanding }\end{array}$ & 9 & 8 & 9 & 8.67 & Very good \\
\hline & $\begin{array}{l}\text { Color combination is } \\
\text { appropriate }\end{array}$ & 9 & 8 & 10 & 9.00 & Very good \\
\hline \multirow[t]{3}{*}{ Time } & & 9 & 10 & 9 & 9.33 & Very good \\
\hline & $\begin{array}{l}\text { The time to work on a SAS } \\
\text { is proportional }\end{array}$ & 9 & 9 & 9 & 9.00 & Very good \\
\hline & Average Score & 8.86 & 8.57 & 9.14 & 8.86 & Very good \\
\hline
\end{tabular}

Table 6 presents the results of SAS assessments conducted by experts with the value given to SAS having a range of 1 to 10 results as follows: Expert 1 (V1) gives an average value of all components of 8.86, for expert 2 (V2) gives a value of 8.57, and expert 3 (V3) gives a value of 9.14. So, the average value of the three experts is 8.86 with the criteria that the value is very good. The three expert validators also stated that the prototype SAS Basic Concept of Elementary School Science developed was valid and feasible to use (Nieveen \& Folmer, 2013; Suhandi \& Wibowo, 2012; Suyidno et al., 2017; Dwikoranto et al., 2019).

The prototype validation stage of the learning device gets some suggestions for improvement given by the expert validator, namely the cover must look for images that represent the contents of the learning device, explain the relationship between the concept and the application more coherently (the concept, the application of the concept, and the discussion 
is changed into an example of the application, concept, and discussion), adding examples of activities that are simpler and related to scientific consistency and phenomena, the language used is more communicative and uses terms that are easily understood to represent concepts (Widianingtiyas et al., 2015; Dwikoranto et al., 2018). Suggestions about wrinkles in explaining concepts and adding student activity are very good for improving this device. This is expected to make it easier for students to master the concepts conveyed. The validator also suggests pictures of illustrations of verbal representation, drawings, graphics, and mathematics must be explained in detail and the explanations must really contain everything that supports scientific consistency.

\section{CONCLUSION}

Based on the results and discussion it can be concluded that this research development results in a research product in the form of a multi representation-based concept attainment tutorial model along with valid supporting tools to improve the mastery of concepts and scientific consistency of prospective teacher students. The Concept Attainment model developed includes valid content and constructs, and is supported by valid DAT, TPU, and SAS devices. The results of the content validation show that the model was developed according to the needs and design of the model based on the novelty of scientific knowledge. The results of construct validation show that there is mutual consistency between the model overview, theoretical and empirical support, learning planning, learning implementation, managing the learning environment, assessment, and evaluation. Learning tools developed as a form of operational models have very valid and reliable criteria.

This research is limited to being conducted in the distance learning unit area of the Open University of Surabaya, East Java Region. Furthermore, it can be done in various areas of the Open University in all regions of Indonesia and abroad. The material under study can also be varied and can be tested in other subjects.

\section{ACKNOWLEDGEMENTS}

Thank you to the Open University Indonesia for supporting and funding this research. Thank you for all respondents and validators in this research.

\section{REFERENCES}

Admoko, Endrias, N., \& Yogi. (2017). Profil mahasiswa pemrogram matakuliah konsep dasar IPA di SD [Student profile of Natural Science Basic Program subjects in elementary school]. Citra Mandiri Adv.

Arends, R. I. (2012). Learning to teach (9th ed.). McGraw-Hill Education.

Borich, G. D. (2011). Observation skills for effective teaching (6th ed.). Pearson.

Dufresne, R. J., Gerace, W. J., \& Leonard, W. J. (1997). Solving physics problems with multiple representations. The Physics Teacher, 35(5), 270-275. https:// doi.org/10.1119/1.2344681

Dwikoranto, Madlazim, Erman. (2019). Project based laboratory learning as an alternative learning model to improve sciences process skills and creativity of physic teacher candidate. Journal of Physics: Conference Series, 1387. https://doi.org/10.1088/17426596/1387/1/012074

Dwikoranto, Setiani, R., Madlazim, \& Erman, E. (2018). Validity of project based laboratory learning: An innovative physics laboratory learning to prepare sciences process skills and creativity of physics teacher candidate. In Z. Zheng \& Z. Xi (Eds.) Atlantis Highlights in Engineering - Proceedings of International Conference on Science and Technology (ICST 2018). (pp. 912-917). Atlantis Press. https:/doi.org/10.2991/icst-18.2018.184

Hake, R. R. (1998). Interactive engagement versus traditional methods: A six thousand student survey of mechanics test data for introductor physics courses. American Journal of Physics, 66(1), 66-74. https:// doi.org/10.1119/1.18809 
Homer, D., \& Bowen-Jones, M. (2014). Oxford IB diploma programme: Physics course companion. Oxford University Press.

Kurnaz, M. A., \& Arslan, A. S. (2014). Effectiveness of multiple representations for learning energy concept: Case of Turkey. Procedia - Social and Behavioral Sciences, 116, 627-632. https://doi.org/10.1016/j.sbspro.2014.01.269

Ministry of Education. (2006). Peraturan menteri pendidikan nasional Republik Indonesia standar isi untuk satuan pendidikan dasar dan menengah [Minister of Education Regulation No.22.2006 concerning content standards for primary and secondary education units] (No. 22.2006). Ministry of Education of Indonesia.

Murtono, Setiawan, A., Asmawi, Z., \& Dadi, R. (2015). Profile of the consistency of representation and scientific consistency of prospective physics teachers on newton's law materials, business, and energy. Wahana Physics Education Journal UPI, 96-101.

Nieminen, P., Savinainen, A., \& Viiri, J. (2010). Force concept inventory-based multiple-choice test for investigating students' representational consistency. Physical Review Special Topics Physics Education Research, 6(2), 20109. https:// doi.org/10.1103/PhysRevSTPER.6.020109

Nieveen, N., \& Folmer, E. (2013). Formative evaluation in educational design research. In T. Plomp and N. Nieveen (Eds.), An Introduction to Educational Design Research (pp. 89-101). SLO - Netherlands Institute for Curriculum Development.

Plomp, T. (2013). Educational design research: An introduction. In T. Plomp and N. Nieveen (Eds.), An Introduction to Educational Design Research (pp. 10-51). SLO - Netherlands Instrument for Curriculum Development.

Sari, A. P., Feranie, S., \& Karim, S. (2015). Penerapan pembelajaran berbasis masalah dengan pendekatan multirepresentasi untuk meningkatkan prestasi belajar dan konsistensi ilmiah berbasis multirepresentasi pada materi elastisitas. Jurnal Penelitian dan Pengembangan Pendidikan Fisika, 1(2), 45-50. https:// doi.org/10.21009/1.01208

Setyaningrum, E. E. (2014). Penerapan pembelajaran interaktif dalam model pencapaian konsep untuk meningkatkan hasil belajar siswa pada materi usaha dan energi. Jurnal Inovasi Pendidikan Fisika, 3(2).

Setyowati, T., Surasmi, W. A., Widuroyekti, B., Sambada, D., Pramonoadi, Setiani, R., Dwikoranto, \& Faqih, A. (2019). Tutorial model with student's pictorial riddle based worksheet for practicing representation capabilities of prospective teacher candidate. Journal of Physics: Conference Series, 1387. https://doi.org/10.1088/17426596/1387/1/012128

Suhandi, A., \& Wibowo, F. C. (2012). Pendekatan multirepresentasi dalam pembelajaran usahaenergi dan dampak terhadap pemahaman konsep mahasiswa. Jurnal pendidikan fisika Indonesia, 8(1). https://doi.org/10.15294/jpfi.v8i1.1988

Sumardi, Y., Rumanta, M., Sapriati, A., Sukiniarti, Ratnaningsih, A., Iryani, K., Syulasmi, A., Safitri, H., Herawati, \& Padiangan, P. (2008). Konsep dasar ilmu pengetahuan alam di sekolah dasar. Universitas Terbuka.

Sutopo, Sari, A. \& Wartono, (2015). Penggunaan multi representasi untuk meningkatkan penguasaan konsep siswa SMA pada materi hukum II Newton. In A. Widiyatmoko, A. V. Amalia, E. N. Savitri, \& R. D. Hardianti (Eds.), Seminar Nasional IPA VI (pp. 270-280). CV. Swadaya.

Suyidno, Nur, M., Yuanita L., \& Prahani, B. K. (2017). Validity of creative responsibility based learning: An innovative physics learning to prepare the generation of creative and responsibility. IOSR Journal of Research \& Method in Education (IOSR-JRME), 7(1), 56-61 https://doi.org/10.9790/7388-0701025661

Taqwa, M. R. A., Zainuddin, A., \& Riantoni, C. (2020). Multi representation approach to increase the students' conceptual understanding of work and energy. Journal of Physics: Conference Series, 1567. https://doi.org/10.1088/1742-6596/1567/3/032090 
Tresnaningsih, S., Supardiono, Munasir, Dwikoranto, Pramonoadi, Setyowati, T., Sambada, D., \& Setiani, R. (2019). Effectiveness concept attainment tutorial based multi representation of mastery concepts and scientific consistency college student. Journal of Physics: Conference Series, 1387. https://doi.org/10.1088/1742-6596/1387/1/012073

Ulfarina, L. (2010). Penggunaan pendekatan multi representasi pada pembelajaran konsep gerak untuk meningkatkan pemahaman konsep dan memperkecil kuantitas miskonsepsi siswa SMP. [Master's thesis, Indonesia University of Education]. UPI Repository. http://repository.upi.edu/id/eprint/9671

Widianingtiyas, L., Siswoyo, S., \& Bakri, F. (2015). Pengaruh pendekatan multi representasi dalam pembelajaran fisika terhadap kemampuan kognitif siswa SMA. Jurnal Penelitian dan Pengembangan Pendidikan Fisika, 1(1), 31-38. https:// doi.org/10.21009/1.01105

Zou, X. (2010). The use of multiple representation and visualization in student learning of introductory physics: An example from work and energy. [Doctoral dissertation, The Ohio State University]. OhioLINK. http://rave.ohiolink.edu/etdc/view?acc_num $=$ osu1488203158826859

\section{Author (s):}

Pramonoadi

UPBJJ-UT, Open University Surabaya,

Campus C Mulyorejo Unair 60115, Indonesia

Email: pramonoadi@ecampus.ut.ac.id

Sri Tresnaningsih

UPBJJ-UT, Open University Surabaya

Campus C Mulyorejo Unair 60115, Indonesia

Email: sritresnaningsih@ecampus.ut.ac.id

Abdul Faqih

UPBJJ-UT, Open University Surabaya

Campus C Mulyorejo Unair 60115, Indonesia

Email: abdulfaqih@ecampus.ut.ac.id

Rahyu Setiani

Bhinneka PGRI University of Tulungagung,

Jl. Mayor Sujadi Timur No.7, Ploso Kandang, Tulungagung 66221, Indonesia

Email: rahyusetiani@gmail.com

* Dwikoranto (Corresponding Author)

Department of Physics, Faculty of Mathematics and Natural Science,

Universitas Negeri Surabaya,

Jl. Ketintang, Surabaya 60231, Indonesia

Email: dwikoranto@unesa.ac.id 